\title{
Why do you hate me so much? An exploration of religious freedom from the perspective of African religion(s)
}

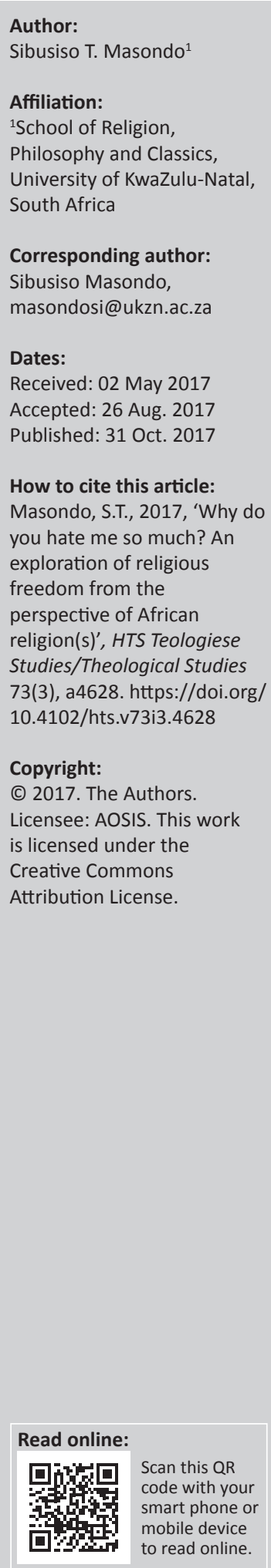

The advent of the 1996 constitution and the promotion of freedom of religion gave space to previously discriminated religious traditions to flourish. There have been a number of revivals of aspects of African Traditional Religion. The Bill of Rights guarantees Religious Freedom but tends to limit it to Freedom of belief. People have every right to believe and practice as long as their practice is in line with the law. This paper is a reflection on the difficulties posed by the notion of Religious Freedom as contained in the 1996 South African constitution for practitioners of African Indigenous Religions and other minority religions. In a case that captured the imagination of the legal fraternity, Gareth Prince, a practicing Rastafarian, was prevented from joining the Bar of the Western Cape because of a prior conviction of being caught in possession of dagga, an illegal substance. He argued that he used cannabis as part of his religious observance. Justice Ngcobo, in his judgement dismissing the case, made it very clear that 'the right to freedom of religion is not absolute'. In other words, religious practices need to fall within the provisions of the law of the land. At the core of our argument is that the intellectual and cultural resources that were mobilised in writing the South African constitution failed to reflect on the religious practices of indigenous people and other minority religions.

\section{Introduction}

It is a well-documented fact that African Traditional Religion was discriminated against by missionaries, as well as colonial and apartheid governments (Gray 1990:2). There were even predictions that ATR would cease to exist and be replaced by Christianity. Professor John Mbiti, one of the pioneers for the study of African religion, predicted in 1970 that ATR would run out of practitioners at the turn of the millennium and would bequeath all her values to Christianity. He, like Edward Blyden almost a century before, believed that Christianity was the highest form of religious expression and all these other religions with their positive values formed what he called preparatio evangelica [preparation for the Gospel]. In fact:

Mbiti was concerned to show that there were ways in which the Gospel could be interpreted as the fulfilment of African cultural values and so be brought into fruitful contact with them to the benefit of African expression of the faith. (Bediako 1993:373)

He went further to assert that 'Africans were to receive freedom, maturity, selfhood, and fulfilment in Christianity' (Bediako 1989:60).

African traditionalist and academic Nokuzola Mndende (1998a) pointed out that under these regimes the public profile of African knowledge systems declined and African religion became an 'underground praxis'. African knowledge systems were systematically undermined during colonialism and Apartheid. Part of the process of undermining these knowledge systems was to instil a sense of inferiority among Africans (Comaroff \& Comaroff 1989). The point is further elaborated by Historian Les Switzer that 'the strength of the mission enterprise stemmed, in part, from its ability to shape the convert's perception of reality in such a way that its authority was legitimated' (1993:117). Historian of religion David Chidester (1994; 1996) has documented a history of intolerance towards African religious traditions from the time when settlers set foot on South African soil. Initially, there was a denial that Africans had a religion, based on the idea that Africans had no idea of a Supreme Being or God. Such an assertion implied that Africans were at the same level as animals and therefore had no human rights, thus justifying the seizure of land and oppression of Africans in general. In the early encounters between the missionaries and AmaXhosa, 'many missionaries convinced themselves that the Xhosa were "not only without a knowledge of a true God, but without the knowledge of any God true or false"' (Crais 1992:101). 
For these missionaries, the land of AmaXhosa was an 'extensive moral wilderness' (Crais 1992:101). Later there was acceptance that Africans did have religion, but it was considered inferior, as it was 'superstition'.

The 1996 Constitution not only ushered in a dispensation of racial inclusiveness and human rights, but it also introduced freedom of religion as one of the rights. There was an attempt by the writers of the Constitution to avoid making the same mistakes as the previous regimes by privileging one religion over others, and such constitutional provisions sought to ensure freedom for all religions to be practiced without fear or prejudice and also to provide protection from religious discrimination or coercion. The Constitution recognised that South Africa is a religiously plural society and aimed to protect people's rights to belong to any religion without fear of being discriminated against or persecuted. Freedom was also extended to those who hold no religious beliefs. This protection of religious freedom should be understood as part of the project of cultivating tolerance in a previously deeply divided society. Section 15 (1) of the Bill of Rights says 'Everyone has the right to freedom of conscience, religion, thought, belief and opinion'. However, it is critical to understand that religious freedom as defined by the constitution has limitations. Ebrahim Moosa (2000), the South African Islamic legal and history scholar, holds the view that the South African Constitution has a dualistic view of religion, that is, religion as an abstract and unarticulated dogma and religion as practice. The translation of belief into practice is severely limited by the constitution. The constitution individualises religion and confines it to a private space. If religion appears in public spaces, it must be regulated in such a way that it does not interfere with the norms and values of the secular state. Individuals can hold beliefs and put them in practice as long as they do not violate the constitution or the law. This paper is a reflection of how African religion and culture have experienced freedom of religion by looking at three cases; firstly, eThekwini Municipality dealing with the 'dumping' of chickens and other items by the AICs and other traditional practitioners on the beaches; secondly, a Rastafarian family being forced to send their children to school amid protestations about the content of the school curriculum; and thirdly, Jacob Zuma as a man who openly embraced African traditions and culture.

The 1996 constitution, which was heralded as the most liberal in the world, and the Bill of Rights compounded the problems for practitioners of ATR by not pronouncing itself clearly as being in support of African religious heritage. The failure by the founding document of the New South Africa to resolve these issues could be attributed, to a large extent, on the dominance of western law and its categories. The ANC, which played a critical part in the drafting of the constitution and has governed South Africa since 1994, was started by educated, Christianised, and urbanised Africans from various parts of the country, whose attempts at integration into the colonial political and economic set up was frustrated (Limb 2002:61). Historian Peter Limb (2002) gives a useful account of how some of the founding members of the ANC were elites caught up in the British colonial world battling for acceptance but being denied access by both the colonial government and the Imperial crown. These leaders believed in 'British sense of justice', legalism and 'British fair play'. Their policies were premised on a vision of realising a certain type of progress defined in terms of European modernity. Their vision of South Africa, and Africa in general, was the conversion of all to Christianity and the embrace of European modernity in terms of commerce and industry. This is captured succinctly by John L Dube, the first president of the African Native National Congress, when he said that 'Christianity will usher in a new civilization, and the "dark continent" will be transformed into a land of commerce and Christian institutions' (Karis \& Carter 1972:69). He reiterates a point that European missionaries had been making since their arrival in South Africa. He was clearly in favour of abandoning all of African religion and culture for the new world view, which had the potential of transforming how Africa does her business.

Firstly, the idea of religious freedom contained in the South African Bill of Rights is premised on the definition of a person as autonomous. In his explication of the autonomous person, African Philosopher Kwame Anthony Appiah referred to Immanuel Kant (2001) who:

argued that our equality is grounded in our shared human capacity to reason. ... he developed the idea of autonomy: the idea of a person's being self-governing, ruling him or herself, rather than being ruled from outside. (p. 311)

Social Anthropologists Comaroff and Comaroff (2001) are critical of such a definition as they say:

From our disciplinary perspective, 'the autonomous person', that familiar trope of European bourgeois modernity (Taylor 1989), is a Eurocentric idea. And a profoundly parochial, particularistic one at that. To be sure, the very notion that this generic person might constitute a universal is itself integral to its Eurocultural construction, a part of its ideological apparatus. What is more, 'the autonomous person' - the definite, singular article - describes an imaginaire, an ensemble of signs and values, a hegemonic formation: neither in Europe, nor any place else to which it has been exported, does it exist as an unmediated sociological reality. (p. 267)

Given the multicultural and multireligious nature of South Africa, non-Western ideas about the meaning and content of personhood are not considered. There was no serious consideration of implications of such constructions on people with alternative constructions. There was a certain normatisation of western constructions of personhood and by extension human rights.

Secondly, the idea of religion is based on a Western idea, which has abstracted religion and banished it to the level of belief. Jonathan Z. Smith, in his contribution to Mark C. Taylor's (1998) Critical Terms form Religious Studies, traces how the concept of religion evolved in the West. The critical point was in the 18th century when religion was separated from 
performance. The consequence of this divorce was that religion was increasingly abstracted and eventually privatised. According to Smart Christianity is often used by scholars and religious practitioners as a benchmark against which all religions are compared. In her reflection of a meeting with Mandela, Mndende pointed out that Mandela told them that African religious heritage is 'culture'. In the hierarchies of power, according to legal academic Tom Bennett, religion has a better legal standing than culture. Such classification meant that ATR in its practical application would not enjoy similar protections as other religions. The state has taken upon itself the right to decide what is in the interest of society.

The critical question on Religious Freedom as it appears in the Bill of Rights is 'To what extent does the Western development of a relation between law and religion, as reflected in the South African Constitution, accommodate African religion and culture?' (Du Toit 2006:690).

\section{African Traditional Religion in a democratic South Africa}

This section gives a picture of how ATR has managed to adapt to changing socio-economic and political situation in South Africa. It goes through a number of practices that have become more visible in the post-1994 dispensation. The pre1994 dispensation did not allow for the promotion of religions other than Christianity. The South African Broadcasting Corporation (SABC) only had programmes of a Christian nature. There was an imposition of Western Christian values on the rest of the population in South Africa through National Christian Education and other cultural organs of state (Kwenda 2003:68). The post-1994 dispensation opened up space for ATR and other marginalised traditions; space to have a public voice and profile. This included the invitation of traditional practitioners to offer prayers at presidential inaugurations, as well as, the establishment of Freedom Park. The dominant public view of ATR was generally negative before 1994. For some African Christians, it was deemed an embarrassment to be seen to be engaged in traditional rituals and practices or to consult traditional religious specialists. African Christians continued to practise some of their rituals, albeit without the knowledge of the church establishment. Sacrifices would be performed at night and feasts would be held during the day. These traditional rituals would be referred to as either 'tea' or 'dinner'. Many Christians were uneasy with the use of the traditional terms umsebenzi or tirelo, that is, 'service', because these terms ('tea' and 'dinner') were part of the missionary discourse. The same is true for consultations with the sacred specialists, which would be done secretly. Nokuzola Mndende (1998b) in her book Siyacamagusha accused African Christians of double-talk and serving two masters. She called them oombolo mbini or amalulwane [bats] as they among fellow Christians professed the power of the blood of Jesus but among traditionalists they swore by the power of their ancestors for health and good fortune.
House opening rituals have become a common phenomenon in South African urban areas (Masondo 2011). Anthropologist Patrick A. McAllister (1980) observed that among AmaXhosa, ancestral veneration was adapted to meet the needs of a changing sociopolitical and economic reality. With the advent of migrant labour, African men moved from their familiar rural setting to the unfamiliar and supposedly dangerous urban areas. Ancestral veneration was affected by this movement. There was an appeal to the ancestors for protection on the journey as well as during their stay in the urban areas. Initially, urban areas were not perceived as places where people settled permanently because the rural areas provided all the elements that made one human. The Apartheid era laws did not allow for permanent African settlement in the urban areas. Migrant labour became another aspect of male initiation - in this instance, a man had to prove his manhood through his ability to earn money to both build a homestead and cater for the needs of his wife and children. Post 1994, with Africans being allowed to stay permanently in the urban areas and being able to purchase property in former white suburbs, there developed an idea of 'house opening'. During this ritual, ancestors are invited to come and stay in the house with the owner and the family. The house is dedicated to the ancestors and they are asked to look after and protect it and its inhabitants.

Ukweshwama is one of the rituals that captured the nation's imagination in 2009 and sparked off a fierce debate and contestation that ended up in court. The meaning and content of the celebration were not the contested subjects; instead, the focus was on the perceived cruelty to the animal and by extension the right of King Zwelithini to hold the ceremony. The Animal Rights Activists petitioned the High Court in Pietermaritzburg to instruct the AmaZulu King not to allow the killing of the bull during the celebrations in 2009 because it constituted cruelty to the animal in question. During the ritual, young men are meant to kill the bull with their bare hands as way of showing that they have reached manhood.

Ukweshwama belongs to the cluster of fertility rituals among AmaZulu. Fertility can be theorised as favourable conditions for production and reproduction. For communities that derived their livelihood directly from the land, the relationship with the land and the environment in general was very important. Communities like this were aware of what famine means for their livelihood and their survival. These rituals ensured that people are reminded of their dependence on nature for their livelihood. What is the relevance of an agricultural ritual to a nation that is urbanising and getting more detached from the land? Is it possible to translate the meaning and content of this ritual for a modern society?

Ukweshwama can be described as the ritual of the first fruit. During the ritual, the King - who is the first citizen, the ritual leader (chief priest), the link between the royal ancestors and the rest of the group, the custodian of the tradition - would taste the first fruit of the season. After this all people in the land can eat of the new crop of the season. One of the major aspects of this ritual is thanksgiving to the ancestors for their 
provision. It highlights an important link between people and the environment on which they depend. However, what became part of the public debate was the apparent barbarism and cruelty of killing the bull. Christa Rautenbach (2011) summed up the case of the Animal Rights Africa Trust as follows:

The trust based its application mainly on two grounds. First, it argued that the freedom of conscience and belief allows it to believe in and champion the cause of animal rights. Second, it averred that culture is not an absolute right but is subject to the laws of the land. (p. 64)

The Animal Rights Africa Trust failed to convince the court and it confirmed the right of the King to have the ritual without any alterations. The ecological aspect of ukweshwama was not debated and reports about the custom never mention it. After going to court and winning the contest, King Zwelithini announced during the celebrations in 2009 that he was reinstituting circumcision as part of male initiation.

King Zwelithini ka Bhekuzulu re-introduced circumcision as part of Zulu male initiation in 2009. In order to authenticate his pronouncements, he re-iterated that he is the custodian of IsiZulu culture, customs and tradition. The argument made was that King Shaka in the 1820s did not abolish or terminate the custom, but he suspended it because of the prevailing political conditions. He could not afford to have groups of young men recuperating in the bush while the enemy attacks his territory. The decision was prompted by scientific findings that circumcision lessens the chances of contracting HIV. The move to re-introduce the tradition was justified partly as a measure to fight the escalating rates of new HIV infections in the country. In making the decision he also took into consideration the public outcry about botched circumcisions, especially from the Eastern Cape. Thus, he looked for ways of making a distinction between what he was doing and what others were doing. His spokesperson was at pains to explain that because of the length of time between the time of suspension and the time of re-introduction, AmaZulu had lost the collective memory of how the ritual was performed. No one has the skill to perform the traditional surgery. As a result, help will be enlisted from medical practitioners to train traditional surgeons. Help will also be sought from other indigenous people who continued the custom.

For a tradition to work it must give the impression of being authentic. There is a serious attempt to create a link between the past and the present. Even with obvious changes and new elements the custodians of tradition maintain its authenticity. The authentication process is a creative one. Ali Mazrui (2000)'s work is instructive on this matter, as he maintains that in the process of identity construction there is a degree of nostalgia, amnesia, and false memory. There is convenient forgetting and appeal to an imagined past and thus creating a false memory. There are obvious societal pressures that influence the way tradition is practiced at any time in history. They can be political, economic and social. In this case stopping the spread of HIV was the major reason behind the re-introduction. But there was also criticism of virginity testing. African culture, in general and IsiZulu culture in particular, was accused of being sexist and simply focused on the purity of women and allowing men to do as they please. That, too, was justified and authenticated culturally. From this event, we observe obvious borrowing of expertise and technology from another culture. Such borrowing is not something new, it has been happening from time immemorial. Human history is littered with examples of creative borrowing of material from other cultures and having them redefined or re-baptised for usage with an alien culture. Re-baptism is part of the process of authentication. Alien concepts, practices and technologies are given local meaning, content and symbolism. Thomas Spear (2003) summed up how tradition is made as follows:

Traditions endure for long periods of time, but only because cognitive categories are in dialogical tension with social reality, continually readjusting while simultaneously projecting an image of timeless continuity. But all is not as it seems, for tradition also constitutes a discourse by which people assert present interests in terms of the past. Traditions thus have their own histories, histories that can be recovered by careful excavation of their successive representations. (p. 5)

The subject of animal slaughter for ritual purposes came to the public view after the release of ANC leader Tony Yengeni from prison in January 2007. The family believed that there was something defiling about prison. He had paid his debt to society for fraud and corruption and he needed to be cleansed and restored to his previous position both in the family and the community. The family maintained that it is part of their tradition to slaughter a bull for a cleansing ceremony. Because the animal is dedicated to the ancestors, it is expected that it should bellow to indicate that there is acceptance of the offering in the ancestral world. The public debate that ensued highlighted the tension between culture and aspects of the law. The ability to negotiate these tensions points to the strength of the South African constitution and the institutions that support it.

Rainmaking and fertility rituals were very prominent among Southern African people. Queen Modjadji of Lovedu people in Limpopo Province was known throughout Southern Africa as the rain queen. Eileen Krige (1978), in her important monograph on Lovedu society, The realm of a rain-queen: a study of the pattern of Lovedu society, points out that Modjadji received delegations from all over Southern Africa for her rainmaking abilities. Such rituals indicate people's uncertainty about what nature would do. The aim is to ask nature to be kind to them. Thereby creating a situation where there is harmony between people and nature, which is a critical realisation that humanity depends on nature for survival. For Chirevo Kwenda (2000), through:

going beyond co-operation with nature, itself a progressive step, human beings learn to bear themselves with humility in the face of nature. They sit at its feet to be taught seemingly familiar yet unfathomable wonders, which may contain keys to intractable human problems. They come to see, or rediscover, that nature is there in its own right, for itself primarily, and secondarily for mutual co-operation with humankind. They make the sobering 
discovery that while they need nature, nature does not need them. Perhaps they must not stop there; they must move on in boldness to affirm that human beings are ontologically not caretakers or stewards of anything, but dependents and beneficiaries of the universe. They are only caretakers by default, as a result of their status as naturicides. (p. 258)

The celebration of Nomkhubulwane and ukweshwama were some of the ways in which AmaZulu demonstrated their dependence on nature. Nomkhubulwane is the only daughter of Mvelinqangi. She is the Zulu divinity in female form. She is often associated with fertility. Eileen Krige described Nomkhubulwane as 'Inkosazana, personification of nature, was symbolised as standing on the threshold of summer like a girl at her puberty ceremony, ready for marriage and procreation' (1968:173). In Mazisi Kunene's (1981) words:

Nomkhubulwane is the most central symbol of creation. She establishes the female principle as philosophically the primary force in creation. Through the female principle, the seemingly irreconcilable elements are brought together. Thus the conciliation of opposites and the establishment of balance become the very essence of growth and creation. (pp. XIII-XL)

In Zulu cosmology Nomkhubulwane is associated with light, rain and fertility. 'Fertility' is an all-encompassing term which includes the land, animals and humans. For the woman, fertility was important, as her womanhood was pegged on her ability to reproduce. Keeping pure and celebrating Nomkhubulwane meant that once married the woman would be able to reproduce. In the past she was celebrated locally by a group of girls who would cultivate a field in her honour. Such a field was not tended and no one was allowed to harvest anything from it. The celebration of Nomkhubulwane disappeared during the colonial period, and when it was re-introduced, it was made into a national spectacle, which was led and directed by izangoma. As part of the spectacle, the facilitators included virginity testing. The reasons for the re-introduction of the celebration were twofold: that is, to assert an African cultural identity and to respond to calls for moral regeneration and increased HIV and AIDS awareness.

Virginity testing is meant to encourage girls to abstain from sexual activity until they are married. It serves to keep them pure while at the same time protecting them from HIV and/ or AIDS. The advocates of this practice often invoke 'notions of ukuqhenya [pride] and isithunzi [dignity]' as justification for its continuation. Anette Wickstrom (2010) observed that:

Zulu concepts of virginity have historically been a challenge to Western thought. In contrast to the Victorian concept of chastity, virginity among the Zulus has not previously been associated with abstinence. The most important thing was to avoid penetrative sex, defloration, and thus pregnancy. ... Courtship was, and still is, socially desirable. Thus, virginity is not connected to chastity; both virginity and sexual experience are of great importance. (p. 64)

The practice received a barrage of criticism from various sectors of the South African population. The Commission on Gender Equality has been the fiercest critic of the practice.
Interestingly, the practice not only got support from traditional establishments (Denis 2006:310-326). Denis went on to say that there was political support for initiatives in KwaZulu-Natal and the Eastern Cape, but that changed with the introduction of Children's Act in 2005, which limited testing on children under the age of 16. The Children's Act was criticised by the King Zwelithini as an infringement on the parents' rights to raise their children.

American researcher Kendall (1999) reported that Nomagugu Ngobese re-introduced the festival of Nomkhubulwane in 1995 after an instruction by her ancestors in a dream in 1994. Dreams in African thought are an important and powerful medium of communication with the ancestors. Some are straightforward and could easily be interpreted by any family elder; however, there are complex ones that require the expert knowledge of a sacred specialist. Izangoma not only have specialised knowledge but also have access to the supernatural world; thus, they are able give decisive interpretations. The truth can only be uncovered through accessing the supernatural world. What happens in the seen or visible world is formed and directed from the unseen or invisible world. The truth can only be uncovered by connecting to that world. The sacred specialists are the key to unlocking that truth. In his discussion of sacred specialists, Geoffrey Parrinder (1962) pointed out that:

In all religions one finds experts in religious matters, whether full-time or not. The sacred is dangerous to ordinary mortals, its demands are mysterious and perhaps its character capricious, so that intermediaries are needed who themselves partake of the divine nature. (p. 100).

According to Kendall, many sacred specialists in KwaZuluNatal explained the plight of AmaZulu and other black people as a result of the wrath of the ancestors. The major complaint attributed to the ancestors is that they have been neglected. Rapid urbanisation has seen African culture, tradition and custom being watered down by the influence of other cultures. Africans are accused of turning away from their roots. When the African people turned away from their core spiritual entities, Nomkhubulwane in particular, society lost its balance. With the loss of balance, disease swept through the people (HIV and/or AIDS); there was disharmony in society, which explains the high levels of crime and civil discontent; respect for women was lost, resulting in the high incidence of rape and abuse of women. The political violence of 1980 s and 90 s and civil strife experienced by AmaZulu could be traced back to the neglect of Nomkhubulwane.

\section{Case studies Dead chickens on the beach}

Durban is a religiously plural city. It is characterised by numerous places of worship of different shapes and sizes, that is, mosques, temples, churches, etc., and on different days of the week people from different faith communities visit these places of worship. Another important South African phenomenon is the use of uniforms by mainly African 
churches. Such uniforms are worn when attending church services or going to funerals. The major religious traditions in Durban are Islam, Christianity (various denominations and African Indigenous Churches), Hinduism, African Religion, Judaism and a host of smaller religions. Islam has traditionally been dominated by Indians, Malays and mixed-race people but 'a rising number of indigenous Africans are embracing it' (Booth 2014). Such a development will in the long term give Islam an indigenous flavour along the same ways Christianity was indigenised. There are reported instances of co-operation between different faith communities like 'The Emmanuel Cathedral and the Jumma Masjid (also known as the Grey Street Mosque) have peacefully co-existed side by side, in their towering magnificence, for more than a century' (Asmal 2014).

The local press has been reporting since 2009 about dead chickens and sometimes parts of animals found on the Durban beaches. It was reported that there was a large number of live chickens that are seen feeding in the area close to North beach. There are African rituals that involve sacrificing an animal and offering it to the ancestral spirits that live in the sea. The reports said that people clad in Zionist Church uniforms are often seen performing the sacrifices on the beach and then dumping them in the sea.

The eThekwini Municipality was planning to put in place a by-law that would make it illegal to dump animals in the sea. People who live along the beach and use it regularly were horrified by the sightings of these animals on the beach. Yvonne Ackermann, an inspector at the NSPCA in Amanzimtoti, said:

This is despicable behaviour. Animals should also be treated with dignity ... I often receive phone calls from people claiming to have seen strange activities involving animals. I was a bit sceptical at first but this is a serious crime against innocent animals. (Packree \& Sookha 2005)

Some of the people interviewed told the journalist that such practices were not in good taste and should be stopped. There were even suggestions that there should be one beach set aside for such rituals but Prof Isabel Phiri felt that such a move would be discriminatory. For Phiri:

If you are going to look at health, then there are health concerns when it comes to sewage in the water and people throwing away bottles and papers, so it should be also treated in totality. (Comins 2012a)

\section{Rastafarian family refusal to send children to school}

Rastafarians are popularly known for their vegetarian diet, anti-establishment rhetoric, dreadlocked hair and the use of cannabis as part of worship. AZulu family from Ntshongweni, a little village west of Durban, refused to send their children to school. Sthembiso (Ras Juda) and Thulisile (Motherland) Zulu have five children and none of them were at school in 2014. They refused to send their children to school because, for them, school education is inappropriate and does not equip children with appropriate skills for life. The fact that
Bible was taken away from school made the situation grave as the focus is on sex, rights of children and other devious behaviour (Satanism). Ras Juda was adamant that there was no reason why children were taught inappropriate subjects like human body parts. Ras Juda and Motherland taught their children IsiZulu, English (to communicate with white people when necessary), mathematics (in order to count) as well as the Bible. They displayed a millenarian world view by emphasising preparing their children for standing and accounting before Jehova. Furthermore, they rejected what they called 'Satanic things like credit cards, branded clothes and processed food' (Mkhize 2014).

Vuma FM, a local commercial radio station, solicited the views of Prof Sihawu Ngubane, a cultural expert from the University of KwaZulu-Natal, who stated that religious adherence and beliefs should not be used to deny children education because education will create opportunities for them in future. Prof Ngubane worked with the assumption that there is only one education, western education. In his formulation there is no provision for other forms of education. It does not accommodate the concerns of parents like Rasjuda and Motherland.

Local and national newspapers and the SABC went with the dominant view that this family was mistaken in refusing to send children to school. The parents, Rasjuda (father) has a matric and Motherland (mother) has grade 5 - and that makes them no experts when it comes to matters of education. Mlungisi Gumede, a journalist from Isolezwe, an IsiZulu daily newspaper, says that on his visit to the family he was welcomed by the sight of cannabis plants, 'Uma ungena egcekeni kwaZulu ubingelelwa izihlahla ezinde zomthunzi wezinkukhu ezikake igceke'. The focus of all reporting on this matter was driven by the desire to demonstrate that these parents were depriving them of an education that would help them to participate in the capitalist economy and even acquire material wealth. The value of educational instruction from the parents was not recognised. Interestingly, there is a different response from those parents who formerly decide to home-school their children. Such parents usually have some educational qualification and follow an approved curriculum by the Department of Education. In the case of the Zulu family, there was no formal curriculum and children were not going to have formal qualifications.

Following from the media exposure of this story, the KZN provincial Department of Education negotiated with the parents and eventually the children were allowed to go to school. The parents were convinced that it was in the interest of the children that they be allowed to go to school.

\section{Jacob Zuma}

'Jacob Zuma, South Africa's polygamist president' and 'Jacob Zuma, the polygamous president of South Africa'. The two statements are opening lines of stories on Jacob Zuma admitting to having a child out of wedlock in February 2010 by The Telegraph and The Guardian newspapers. A number of 
local newspapers also ran the same story but the words 'polygamous' and 'polygamist' were not given the same prominence. The use of these terms is not innocent. It is meant to convey a message of difference - that is, that Zuma does not adhere to accepted Western value norms and standards. This is part of the narrative that pathologises Africa, Africans as well as African heritage (Owomoyela 1994). Journalist and author Max du Preez, in an opinion piece in Independent Newspapers on 29 October 2013, urged that Zuma should not be judged in terms of his adherence to his traditional cultural and religious beliefs but in terms of his successes and failures as president.

The period leading up to the 2007 ANC Polokwane conference was characterised by various forms of political posturing and debate over who should lead the liberation movement. There were many people who openly campaigned for Jacob Zuma, as well as, those who opposed his candidature. Mosiuoa Lekota, then National Chairperson of the ANC, openly opposed Zuma. Lekota was scathing in his attacks on Zuma, questioning his morals and educational qualifications. He said that the ANC had a proud history of being led by people with university qualifications. For Lekota, Zuma would be an odd one out. When asked about Lekota's attacks, Zuma said to the journalist, 'why does he hate me so much?' At face value, Zuma was asking why he was personally resented by his comrade; however, the attacks and the question were a reflection of undercurrents and contradictions in the ANC since its formation in 1912.

In his closing speech of the ANC Polokwane conference as ANC president in 2007, Zuma (2007) told the delegates that:

\footnotetext{
... as the 12th President of the ANC, succeeding an illustrious list of highly capable leaders of our movement, who steered the organization. ... JL Dube, SM Makgatho, ZR Mahabane, JT Gumede, Pixley ka Isaka Seme, AB Xuma, JS Moroka, AJ Luthuli, OR Tambo, NR Mandela and TM Mbeki.
}

Zuma is different to all these leaders because all of them had formal education and university education while he does not have formal education. He openly embraces and practices ATR. He has also declared his Christian beliefs and conviction when he said 'I start from basic Christian principles, ... Christianity is part of what I am; in a way it was the foundation for all my political beliefs' (Chidester 2012:149). In May 2007 he was made an honorary pastor by the Full Gospel Community Church at Ntuzuma north of Durban. This step was seen by some in the Christian circles as a mere publicity stunt and an endorsement of Zuma's candidacy for the ANC presidency. Zuma represented that which some in the ANC feared: those who follow in the tradition of JL Dube - who believed that Christianity, Commerce, and Western education were to enlighten the dark continent. In terms of the expectations that were laid down by the founding fathers of the ANC, Jacob Zuma was not supposed to lead because he did not epitomise the kind of person they had in mind. A lot had to change in the presidency when he assumed office. The constitution had not anticipated a person with multiple partners to be president.

\section{Conclusion}

This article has looked at a number of appearances of ATR in public. Often when Africans appeal to institutions of their culture, they are accused of hiding behind tradition. I wish to put forward a different opinion, echoing the view of Jean and John Comaroff: 'it is often a mode of producing new forms of consciousness; of expressing discontent with modernity and dealing with its deformities' (1999:284). Often when these issues are debated in public, the only content of these traditions taken into account are those aspects that people find repugnant. African religio-cultural practices are always treated with suspicion. They are evaluated harshly as the focus is always on the perceived negative aspects and never on the potential benefit these practices would bring to society. Firstly, with regard to Ukweshwama there was no attempt to understand this practice from the perspective of the practitioners. The Animal Rights Africa Trust did not consider the social and environmental aspects of the practice and how stopping the killing of the bull would materially change the experience of the practice by participants. This is a classic case of the conflict between freedom of religion and animal rights. Secondly, the rights of citizens of Durban to clean beaches conflicted with the freedom to perform rituals at the beach and offer sacrifices to ancestral spirits that reside in the sea. Religion has had to conform to the normativity of the secular legal framework that favours western modernity. Thirdly, the fact that Jacob Zuma is openly polygamous, a practice that some find unacceptable, and practices ATR is sometimes thrown at him when people engage in appraising his work as president. The Rastafarian family was forced by the system (Education Department; Department of Social Development) to allow their children to return to school even though they had serious misgivings about the content of the curriculum.

\section{Acknowledgements Competing interests}

The author declares that he has no financial or personal relationships which may have inappropriately influenced him in writing this article.

\section{References}

Asmal, F., 2014, 'Durban puts religious unity on map', viewed 30 April 2015, from http://mg.co.za/article/2014-03-06-durban-puts-religious-unity-on-map

Bediako, K., 1989, 'The roots of African theology', International Bulletin of Missionary Research 13, 58-65. https://doi.org/10.1177/239693938901300203

Bediako, K., 1993, 'John Mbiti's contribution to African theology', in J.O.K. Olupọna \& S.S. Nyang (eds.), Religious plurality in Africa: Essays in Honour of John S. Mbiti, pp. 367-390, Mouton de Gruyter, Berlin.

Booth, L., 2014, 'Have we really got rid of apartheid?', viewed 15 September 2016, from http://www.laurenbooth.org/2014/01/21/have-we-really-got-rid-of-apartheid/

Chidester, D., 1994, Authentic forgery or forging authenticity: Comparative religion in South Africa, Inaugural Lecture No.186, University of Cape Town.

Chidester, D., 1996, Savage systems: Colonialism and comparative religion in Southern Africa, University Press of Virginia, Charlottesville, VA.

Chidester, D., 2012, Wild religion: Tracking the sacred in South Africa, University of California Press, Berkeley, CA.

Comaroff, J. \& Comaroff, J.L., 1989, 'The colonization of consciousness in South Africa', EconomyandSociety 18(3),267-296.https://doi.org/10.1080/03085148900000013

Comaroff, J. \& Comaroff, J.L., 1999, 'Occult economies and the violence of abstraction: Notes from the South African postcolony', American Ethnologist 26(2), 289-303. 
Comaroff, J. \& Comaroff, J.L., 2001, 'On personhood: An anthropological perspective from Africa', Social Identities 7(2), 267-283. https://doi.org/10.1080/135046 30120065310

Comins, L., 2012a, 'Beach sacrifices raise ire of public', viewed 30 April 2015, from http://www.iol.co.za/saturday-star/beach-sacrifices-raise-ire-of-public1.1243611 ?ot=inmsa.ArticlePrintPageLayout.ot

Comins, L., 2012b, 'Grisly sights for locals on beaches', viewed 30 April 2015, from http://www.iol.co.za/news/south-africa/kwazulu-natal/grisly-sights-for-localson-beaches-1.1242536\#.U-ngVeOSxrU

Crais, C.C., 1992, White supremacy and Black resistance in pre-industrial South Africa: the making of the colonial order in the Eastern Cape, 1770-1865, Cambridge University Press, Cambridge and New York.

Denis, P., 2006, 'The rise of traditional African religion in post-apartheid South Africa', Missionalia 34(2/3), 310-323.

Du Plessis, L.M., 2009. 'Religious freedom and equality as celebration of difference: a significant development in recent South African constitutional case-law', PER: Potchefstroomse Elektroniese Regsblad 12(4), 10-34.

Du Plessis, L.M., 2001, 'Freedom of or freedom from religion? An overview of issues pertinent to the constitutional protection or religious rights and freedom in "the New South Africa"', Birmingham Young University Law Review 2, 439-466.

Du Toit, C.W., 2006, 'Religious freedom and human rights in South Africa after 1996 Responses and challenges', Brigham Young University Law Review 3, 677-698.

Gray, R., 1990, Black Christians and white missionaries, Yale University Press, New Haven, CT.

Gumede, M., 2014, 'Izingane zamaRasta azilubhadi esikoleni', viewed 12 August 2014, from http://www.iol.co.za/isolezwe/izingane-zamarasta-azilubhadi-esikoleni1.1632952\#.U-nceeOSxrU

Karis, T. \& Carter, G.M., 1972, From protest to challenge: A documentary history of African politics in South Africa, 1882-1934, vol. 1, Hoover Institution Press, Stanford, CA.

Kendall, 1999, 'The role of Izangoma in bringing a Zulu Goddess back to her people', The Drama Review 43(2), 94-117. https://doi.org/10.1162/105420499760265226

Krige, E.J., 1968, 'Girls' puberty songs and their relation to fertility, health, morality, and religion among the Zulu', Africa 38(2), 173. https://doi.org/10.2307/1157245

Krige, E.J., 1978, The realm of a rain-queen: A study of the pattern of Lovedu society AMS Press, New York.

Kunene, M., 1981, Anthem of the decades: A Zulu epic dedicated to the women of Africa, Heinemann, London.

Kwenda, C.V., 2000, 'Beyond patronage: Giving and receiving in the construction of civil society', in J.R. Cochrane \& B. Klein (eds.), Sameness and difference: Problems and potentials in South African Civil Society, pp. 243-268, The Council for Research and potentials in South African Civil Society,
in Values and Philosophy, Washington, DC.

Kwenda, C.V., 2003, 'Cultural justice: The pathway to reconciliation and socia cohesion', in D. Chidester, P. Dexter \& W.G. James (eds.), What holds us together: Social cohesion in South Africa, pp. 67-80, HSRC Press, Cape Town.

Limb, P., 2002, 'Early ANC leaders and the British world: Ambiguities and identities', Historia 47(1), 56-82.
Makhaye, C., 2007, 'Church lauds Zuma as honorary pastor', viewed 30 April 2015, from http://www.iol.co.za/news/politics/church-lauds-zuma-as-honorary-pastor-351656

Masondo, S., 2011, 'The practice of African traditional religion in contemporary South Africa', in T.W. Bennett (ed.), Traditional African religions in South African Law, pp. 19-36, UCT Press, Cape Town.

Mazrui, A.A., 2000, 'Cultural amnesia, cultural nostalgia and false memory: Africa's identity crisis revisited', African Philosophy 13(2), 87-98.

McAllister, P.A., 1980, 'Work, homestead, and the shades: The ritual interpretation of labour migration among the Gcaleka', in P. Meyer (ed.), Black villagers in industria society: Anthropological perspectives on labour migration in South Africa, pp. 205-253, Oxford University Press, Cape Town.

Mkhize, J., 2014, 'School's out for Rasta kids!', viewed 12 August 2014, from http:// dailysun.mobi/news/read/4153/school-s-out-for-rasta-kids

Mkhize, J. \& Phungula, W., 2014, 'School starts for Rasta kids', viewed 12 August 2014 from http://dailysun.mobi/news/read/4312/school-starts-for-rasta-kids

Mndende, N., 1998a, 'From underground praxis to recognised religion: Challenges facing African religions', Journal for the Study of Religion 11(2), 115.

Mndende, N., 1998b, Siyacamagusha, Icamagu Institute, Cape Town.

Moosa, E., 2000, 'Tensions in legal and religious values in the 1996 South African constitution', in M. Mamdani (ed.), Beyond rights talk and cultural talk, pp. 121135, David Philip, Cape Town.

Owomoyela, O., 1994, 'With friends like these... A critique of pervasive antiAfricanisms in current African studies epistemology and methodology', African Studies Review 37(3), 77-101.

Packree, S. \& Sookha, B., 2005, 'Beach sacrifices spark fury', viewed 30 April 2015, from http://www.iol.co.za/news/south-africa/beach-sacrifices-spark-fury1.240724\#.U-njAeOSxrU

Parrinder, E.G., 1962, African traditional religion, SPCK, London.

Rautenbach, C., 2011, 'Umkhosi Ukweshwama: Revival of a Zulu festival in celebration of the universe's rites of passage', in T.W. Bennett (ed.), Traditional African religions in South African law, p. 63-89, UCT Press, Cape Town.

Smart, N., 1997, Dimensions of the sacred: an anatomy of the world's beliefs, Fontana Press, London.

Smith, J.Z., 1998, 'Religion, religions, religious', M.C. Taylor (ed.), Critical terms for religious studies, pp. 269-284, Chicago University Press, Chicago and London.

Spear, T., 2003, 'Neo-traditionalism and the limits of invention in British Colonial Africa', The Journal of African History 44(1), 5. https://doi.org/10.1017/S0021853 702008320

Switzer, L., 1993, Power and resistance in an African society: The Ciskei Xhosa and the making of South Africa, University of Wisconsin Press, Madison, WI.

Wickstrom, A., 2010, 'Virginity testing as a local public health initiative: A "preventive ritual" more than a "diagnostic measure"', Journal of the Royal Anthropological Institute 16, 532-550. https://doi.org/10.1111/j.1467-9655.2010.01638.x

Zuma, J., 2007, '52nd National Conference: Closing speech by ANC President Jacob Zuma', viewed 23 June 2017, from http://www.anc.org.za/content/52nd-nationalconference-closing-speech-anc-president-jacob-zuma 